Discussion Paper No. 06-034

\title{
Aggregate Unemployment Decreases Individual Returns to Education
}

Andreas Ammermüller, Anja Kuckulenz and Thomas Zwick

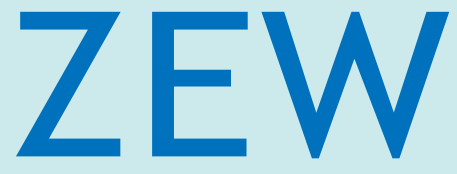

Zentrum für Europäische Wirtschaftsforschung $\mathrm{GmbH}$ Centre for European Economic Research 
Discussion Paper No. 06-034

\title{
Aggregate Unemployment Decreases Individual Returns to Education
}

\author{
Andreas Ammermüller, Anja Kuckulenz \\ and Thomas Zwick
}

Download this ZEW Discussion Paper from our ftp server:

ftp://ftp.zew.de/pub/zew-docs/dp/dp06034.pdf

Die Discussion Papers dienen einer möglichst schnellen Verbreitung von neueren Forschungsarbeiten des ZEW. Die Beiträge liegen in alleiniger Verantwortung der Autoren und stellen nicht notwendigerweise die Meinung des ZEW dar.

Discussion Papers are intended to make results of ZEW research promptly available to other economists in order to encourage discussion and suggestions for revisions. The authors are solely responsible for the contents which do not necessarily represent the opinion of the ZEW. 


\section{Non-technical summary}

An impressive amount of literature shows that individual wages increase with education. Most contributions use so-called Mincer equations that relate numbers of schooling years and other individual characteristics to the individual wage level. The so-called wage curve literature demonstrates that the aggregate unemployment rate also has an impact on individual wages - if aggregate unemployment increases, individual wages decrease significantly. This paper shows that aggregate unemployment affects not only wages but also individual returns to education. On the basis of a theoretical model, we derive the hypothesis that the wages of less qualified employees are affected differently by changes in the unemployment rate than the wages of higher qualified employees. The main reasons for this are that on the one hand the employment opportunities and unemployment risks of higher qualified employees are better isolated against shocks on the labour market than those of less educated employees. On the other hand the wages of the higher educated may react stronger to changes in the business cycle because lower qualified employees rather leave the labour market than accept lower wages. In addition, the wages of higher qualified employees are rather subject to individual bargaining between employer and employee. Individual bargaining is more sensitive to the topical labour market situation. In contrast, collective bargaining wages are rather stable over time.

From our model we conclude that we have to extend the standard Mincer regression to take into account an important factor for individual wages. We include regional unemployment and the interaction term between aggregate unemployment and individual education in order to avoid a misspecification. In our empirical analysis, we use representative individual data and regional panel variation in aggregate unemployment among different German regions. The results show that an increase in regional unemployment by one percent 
decreases returns to education by about 0.005 percentage points. The observed differences in the regional rates of returns can be almost fully explained by differences in the local labour market situation. This implies that empirical studies on returns to education should take aggregate unemployment into account. Especially international comparisons of the returns to education or comparisons of differents points in time could otherwise suffer from omitted variable bias if the unemployment situation differs strongly between countries or across time.

We furthermore check the robustness of our results with respect to the empirical specification and the sample. We split our sample into males and females, East and West Germany, and employees with different tenure. In addition, we take into account unobserved heterogeneity between regions by using fixed effects in a two-step estimation procedure. We also allow for lags in the effect of unemployment on returns to education by including lagged unemployment variables. In addition we control for the endogeneity of the interaction term in the wage equation and instrument it accordingly by its lagged values. Finally, we also run quantile regressions in order to see if low wage earners are less affected than high wage earners. Only the upper wage quantiles experience a reduction in their returns to education if the regional unemployment increases. We find that males are stronger affected than females while the results on tenure are mixed. 


\title{
Aggregate unemployment decreases individual returns to education
}

\author{
Andreas Ammermüller, Anja Kuckulenz, and Thomas Zwick
}

May 2006

Centre for European Economic Research (ZEW)

\begin{abstract}
On the basis of a theoretical model, we argue that higher aggregate unemployment affects individual returns to education. We therefore include aggregate unemployment and an interaction term between unemployment and the individual education level in a standard Mincer equation. Our results show that an increase in regional unemployment by $1 \%$ decreases the returns to education by 0.005 percentage points. This implies that higher skilled employees are better sheltered from labour market changes with respect to their jobs but encounter larger wage changes than less skilled employees. Differences in regional unemployment can in addition almost fully explain the observed large differences in regional returns to education. We use representative individual data and regional panel variation in unemployment between different German regions and for different employee groups. We demonstrate that our results are robust with respect to aggregation bias, time lags and potential endogeneity of the unemployment variable.
\end{abstract}

JEL Codes: C23, J24

Key Words: returns to education, unemployment, regional variation

Acknowledgements

We are grateful to Angel de la Fuente, Melanie Arntz, and Jens Suedekum for helpful comments. 


\section{Introduction}

Financial returns to education are usually measured on the basis of individual wage data (Mincer, 1974; Card, 1999). Traditionally, explanatory variables in these wage regressions are mainly contemporary individual characteristics such as age, qualification, tenure, or gender. In recent years, however, it became fashionable to include additional explanatory variables. Individual skill supply indicators, such as the continuing vocational training history and the labour market history are frequently added in wage regression. Alternatively, the so-called Mincer regression is extended by aggregate skill supply indicators, such as the regional quality of schooling (Campbell, 2001; Card and Krueger, 1992; Barro and Lee, 1996; Card, 1999). The inclusion of these additional explanatory variables often changes the returns to education coefficientsa and improves the quality of the estimation. This suggests that these covariates are essential in the elements of a properly specified Mincer equation.

While skill supply measures are an important determinant of the value of human capital on the labour market, changes in skill demand are also supposed to play a major role. A positive shock in labour demand in a certain region or industry may increase employees' bargaining power. Especially highly qualified employees or employees with key qualifications in this region or industry may profit from such a shock because firms may offer efficiency wages in order to bind employees with certain qualifications (Blanchflower and Oswald, 1990). Therefore, labour market conditions have an impact on returns to education and aggregate unemployment influences employees' wages differently, depending on their qualification. In this paper, we derive this hypothesis formally by expanding a standard wage bargaining model by differentiating between qualification levels.

Our theoretical model therefore suggests that we also should include aggregate unemployment into the measurement of individual returns to education. So far, only rudimentary aggregate skill demand indicators, such as industry sector or 
region, have been used in estimations of the individual returns to education literature, however. Hawley (2004) includes, for example, information on residence in a rural or urban area in order to control for the education expansion on the country side in Thailand and for the rapid economic development in the capital Bangkok and their effects on returns to education. Devereux (2005) shows that individual returns to skills depend on employment changes in industries and on the possibilities of employees to switch from a declining to a growing industry.

There is a broad consensus that cyclical changes in returns to education are linked to shifts in skill demand and supply (Fuente and Ciccone, 2002). Several observers find that skill-biased technological change (Katz and Murphy, 1992; Berman, Bound and Griliches, 1994; Acemoglu, 1998; 1999; Machin and Van Reenen, 1998; Jacobebbinghaus and Zwick, 2002), the business cycle (van Ours and Ridder, 1995), globalisation (Wood, 1995) or capital-skill complementarities (Hamermesh, 1993) have an impact on changes in the skill wage mark-up. These papers usually discuss the change in returns to education on the aggregate level, i.e. for averages of distinct skill groups or income quantiles, or they use time series analyses or international comparisons. Consequently, changes in the composition of employee groups in age, experience, unemployment risk, or other individual characteristics cannot be taken into account (Fitzenberger, 1999). Former evidence suggests, however, that the composition and wage-relevant characteristics of the labour force change during the business cycle or they differ between periods, regions, countries or industry sectors (Devereux, 2005). In order to capture the labour demand effect on the returns to education correctly we therefore should use individual data.

We seek to extend both strands of the literature - the individual returns to education and the macro-economic cyclical education wage mark-up literature - that so far seem to be unconnected. Our attempt is to link both strands by calculating wage returns of education on the individual level in order to avoid 
composition bias. In addition, we add aggregate information on unemployment and its interaction term with education. Here we use the variation across a relatively short period of time and regions in Germany instead of international variation or long time series. The advantage of our regional approach is that, in comparison to international analyses, we reduce the impact of unobserved heterogeneity of labour demand and supply conditions such as different qualification systems, labour market policies or demand shocks between countries.

The empirical contributions that are closest in spirit to our approach are part of the so-called wage curve literature (Nijkamp and Poot, 2005). These papers include regional unemployment in individual earnings equations in order to demonstrate that individual wages react to the regional labour market situation (Blanchflower and Oswald, 1990, 1994; Card, 1995; Baltagi and Blien, 1998; Pannenberg and Schwarze, 1998; Büttner and Fitzenberger, 1998; Faggio and Nickell, 2005). We derive from our theoretical model that, in addition to the negative impact of aggregate unemployment on individual wages, an increase in regional unemployment reduces the returns to education in this region. Hence, the novelty of our approach is to include an interaction term between individual years of education and regional unemployment in our Mincer wage regressions.

The theoretical model suggests that the impact of regional unemployment on individual returns to education differs among employee groups. We find that the effect should be stronger for males than for females, should decrease with tenure and should be smaller for the lower wage quantiles. We therefore distinguish between different employee groups in our regressions and find some empirical support for our hypotheses. In addition, we also take account of estimation problems encountered in our regressions. First, the impact of unemployment might be felt only in later years (Vilhubert, 1999). Second, unemployment and the interaction term between unemployment and education might be endogeneous. Third, there might be unobserved heterogeneity 
between regions. Accordingly, we introduce an innovative two step estimation strategy which entails region fixed effects, lagged interaction terms between unemployment and education levels, and instruments.

The paper proceeds as follows: on the basis of a wage bargaining model, the next section derives the hypothesis that aggregate unemployment has an impact on individual returns to education. In addition, we describe our data basis in the next section. Then we present our estimation strategy. In different specifications we take account of aggregation bias, time lags and potential endogeneity of the unemployment variable. The empirical assessment on the basis of German data shows that the level of unemployment indeed has an impact on individual returns to education. We also assess the estimation bias incurred if this is not taken into account. The last chapter concludes.

\section{Theoretical Background and Description of Data Set}

\subsection{Theoretical Considerations}

In this paper, we integrate regional unemployment into the microeconometric literature on the individual returns to schooling. A large bulk of literature shows that individual employee characteristics such as experience, number of years in education and gender have an impact on individual earnings (Mincer, 1974; Card, 1999; Kuckulenz and Zwick, 2003). Why should we also include aggregate unemployment and the interaction between unemployment and years of education in these estimations of the returns to education?

The empirical wage curve literature consistently shows that regional unemployment has a negative effect on wages of all employees in the region (Blanchflower and Oswald, 1994; Nijkamp and Poot, 2005). There are several convincing theories that explain the negative impact of the regional unemployment rate on individual wages based on individual maximising behaviour of employees or employers (Blanchflower and Oswald, 1994; Card, 1995 or Nijkamp and Poot, 2005). We show here that these models not only 
predict a regional wage curve but with small extensions also can explain an impact of regional unemployment on returns to education. The mechanisms driving our results are similar to those in other standard models. Therefore we present a bargaining model in which unions and firms negotiate how to divide profits.

A standard Nash-bargaining model (compare Nickell and Wadhwani, 1990) between employers and unions assumes the following utility function of the union:

$U=(1-L) W v+L \widehat{W} v$

where $L$ is the probability that the representative union member will be laid off (which is assumed to be random), $v^{-1}$ is the wedge between employers' labour costs and post-tax wages, $W$ is the bargained wage, and $\widehat{W}$ is the expected level of post-tax earnings available to a laid-off worker with:

(1) $\widehat{W} v=\bar{W} v(1-p(\bar{u})(1-B))$.

Here, $B$ is the benefit replacement ratio and $\mathrm{p}(\bar{u})$ is the period for which the worker remains unemployed. The profits of the firms are given by:

$\Pi=A N^{\alpha}-W N$,

with $N$ the number of employees and $A$ a technical progress coefficient. The following Nash-maximand

$$
\max [(1-L)(W v-\widehat{W} v)]^{\beta}\left(\Pi^{*}\right)^{1-\beta}
$$

can be maximized with respect to wage $W$, where $\beta$ is the bargaining power of the union (or the discount rate of the employees). This leads to the following equilibrium wage: 


$$
W=F\left(A / N^{1-\alpha}, \bar{W}, \bar{u}, B, \beta\right), F_{1}, F_{2}, F_{4}, F_{5}>0, F_{3}<0 .
$$

Here, $F_{i}$ is the first order derivative for argument $i$. From equation (2) it is straightforward that the aggregate unemployment rate has a negative impact on the bargained wage level. ${ }^{1}$

We can easily derive different reactions to changes in the unemployment rate for different qualification groups from equation (2) if we take into account that wages and qualificational unemployment rates react differently during the business cycle. Please note that the returns to education decrease with the unemployment rate if the wages of lower skilled employees are less sensitive to changes in the unemployment rate than the wages of the higher skilled employees. Indeed, there are theoretical arguments for a more elastic and for a more inelastic reaction of unskilled wages during the business cycle. The simplest assumption within the framework of the bargaining model is that there are two unions representing low and high skilled employees and that low and high skilled employees work in different firms. In this case, the expected outside option of the employees according to equation (1) depends on the wage in other firms/sectors/regions $\bar{W}$ multiplied by the aggregate unemployment rate.

An argument for a stronger reaction of the unskilled bargained wages on the business cycle - or in other words an increase in the returns to education with the regional unemployment rate - is related to the relative employment rates by qualification. During depressions the employment rate of less skilled employees increases more than proportionally, while the unemployment rate of higher skilled employees is better isolated against the business cycle (Card, 1995; Van Ours and Ridder, 1995; Reinberg and Hummel, 2002). A simple

1 Our empirical model estimates individual wage regressions including aggregate unemployment using fixed effects. Our observation period is rather short and therefore we assume that we can drop the assumedly virtually unchanged benefit replacement ratio 
regression of the impact of aggregate unemployment on qualification-specific employment rates on the basis of the representative German Microcensus indeed shows a significant negative correlation that is steeper for high qualified employees than for low qualified employees (compare the descriptive analysis in Figure 1). ${ }^{2}$ A reason for a lower impact of aggregate unemployment on qualification-specific employment rates is that firms smooth employment of those workers with high turnover costs, while workers who are easier replaced suffer job losses during depressions (Oi, 1962; Mincer, 1991; Van Ours and Ridder, 1995; Card 1995). Labour turnover costs increase, for example, with specific human capital but also with general human capital if it complements specific human capital.

The stronger fluctuation of the unemployment rate mirrors the findings of the stronger impact of the business cycle on the employment rate, compare Figures $2 \mathrm{a}$ and $2 \mathrm{~b}$ for East and West Germany. This again empirically demonstrates that highly qualified employees are better isolated against changes in the business cycle in their unemployment risk than less qualified employees. Finally, the average unemployment period also is an element of equation (2) multiplied by $\bar{u}$. We know that the average unemployment period of high skilled employees is clearly shorter than that of low skilled employees (Lauer, 2003; Wilke, 2004). These effects all lead to a stronger expected reduction of the outside option and as a consequence of the bargaining power of less qualified employees if unemployment increases. This means, however, that wages of low skilled employees should be more sensitive to changes in the aggregate unemployment rate.

$B$, the technology parameter divided by the number of employees $\mathrm{A} / \mathrm{N}^{1-\alpha}$, the bargaining power of the unions $\beta$ and the outside wage option $\bar{u}$ from our regression.

${ }^{2}$ The coefficient of the aggregate unemployment rate on the employment share of the low educated (no or lower vocational education) is -0.0085 while the coefficient for the high educated (tertiary or higher vocational education) is -0.0066 , controlling for regions. Both coefficients are significant at the one percent level. The difference between the coefficients is significant at the ten percent level. 

Figure 1: Correlation between aggregate unemployment and
qualification-specific employment

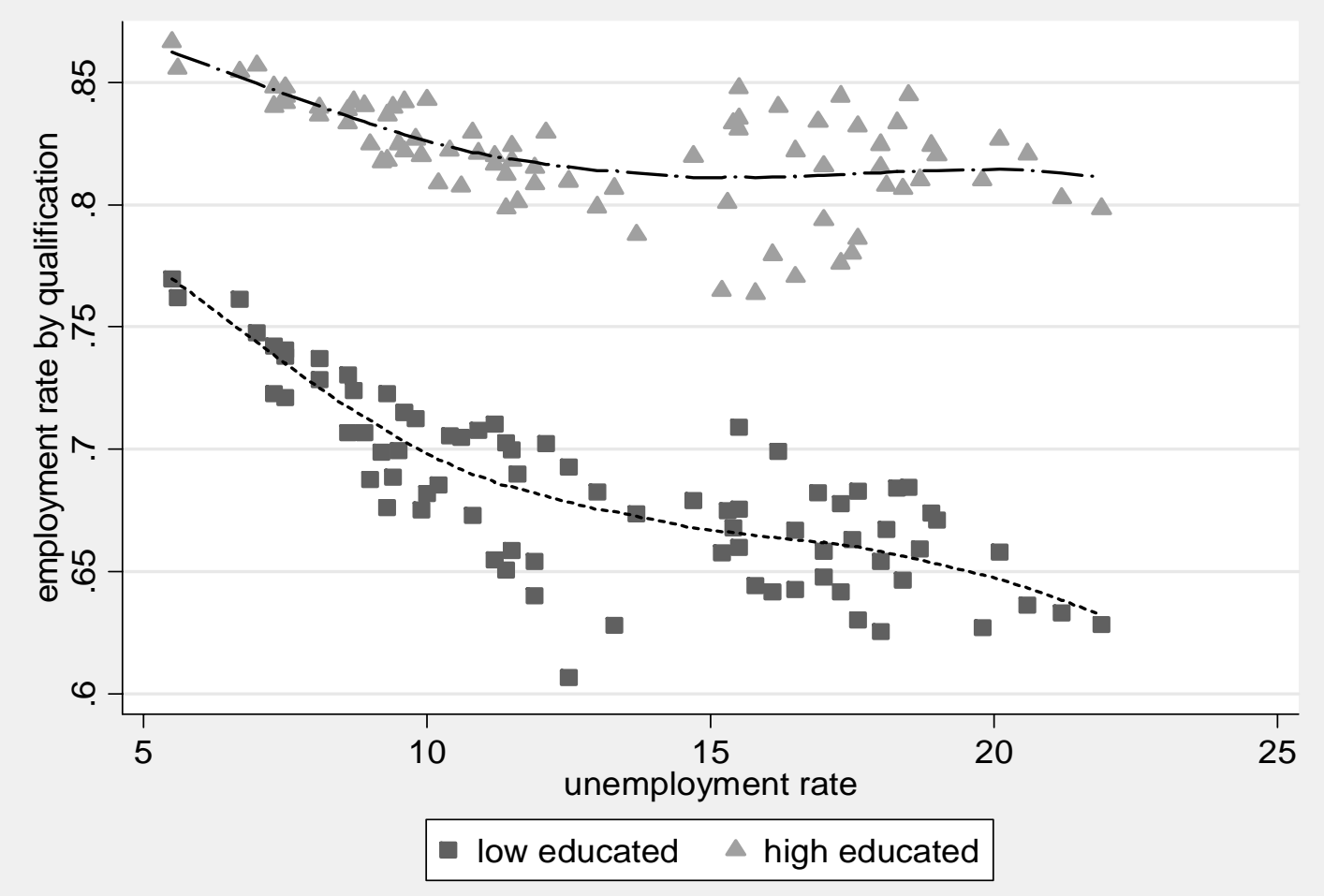

Source: Microcensus, waves 1996-2000.

Comments: The low educated include persons with no or lower vocational education (Lehre) while the high educated have tertiary or higher vocational education (Meister). The dotted lines stem from smoothed regressions.

Besides the expected unemployment risk and duration, also the wage in other firms, regions or sector plays a role in the wage determination of our bargaining model, however. We argue that wages in alternative jobs for higher skilled employees are more elastic with respect to changes in the unemployment rate than wages for lower skilled employees. One reason might be that lower skilled employees are frequently subject to collective bargaining and wages of lower skilled employees are rigid with respect to changes in the business cycle (Krugman, 1994). Higher educated employees bargain directly with their employers and therefore their wages might be more closely related to the contemporary tightness of the labour market. While higher skilled employees might be better isolated against the business cycle in their unemployment risks, this may also lead to a stronger job competition on the 
free jobs in times of oversupply. Accordingly, a stronger wage reaction during the business cycle for this group of employees is likely (Van Ours and Ridder, 1995). Another reason for a stronger wage reaction of higher skilled employees to changes in labour market tightness may be relatively generous replacement rates for low skilled employees that induce this group of workers to leave the labour market instead of accepting a lower wage.

Figure 2a: Unemployment rates in Western Germany by qualifications

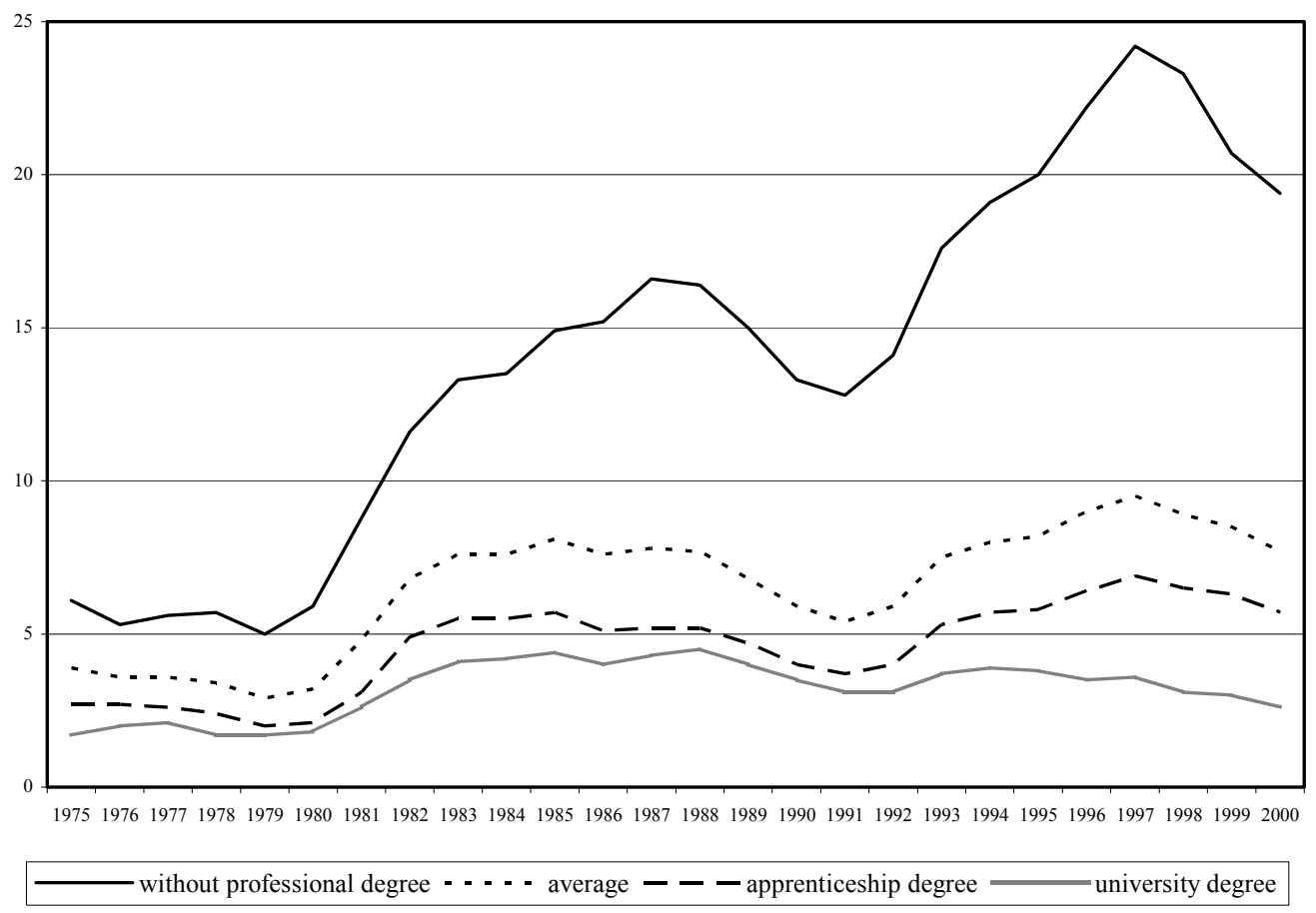

Source: IAB-Kurzbericht Nr. 9/2003 
Figure 2b: Unemployment rates in Eastern Germany by qualifications

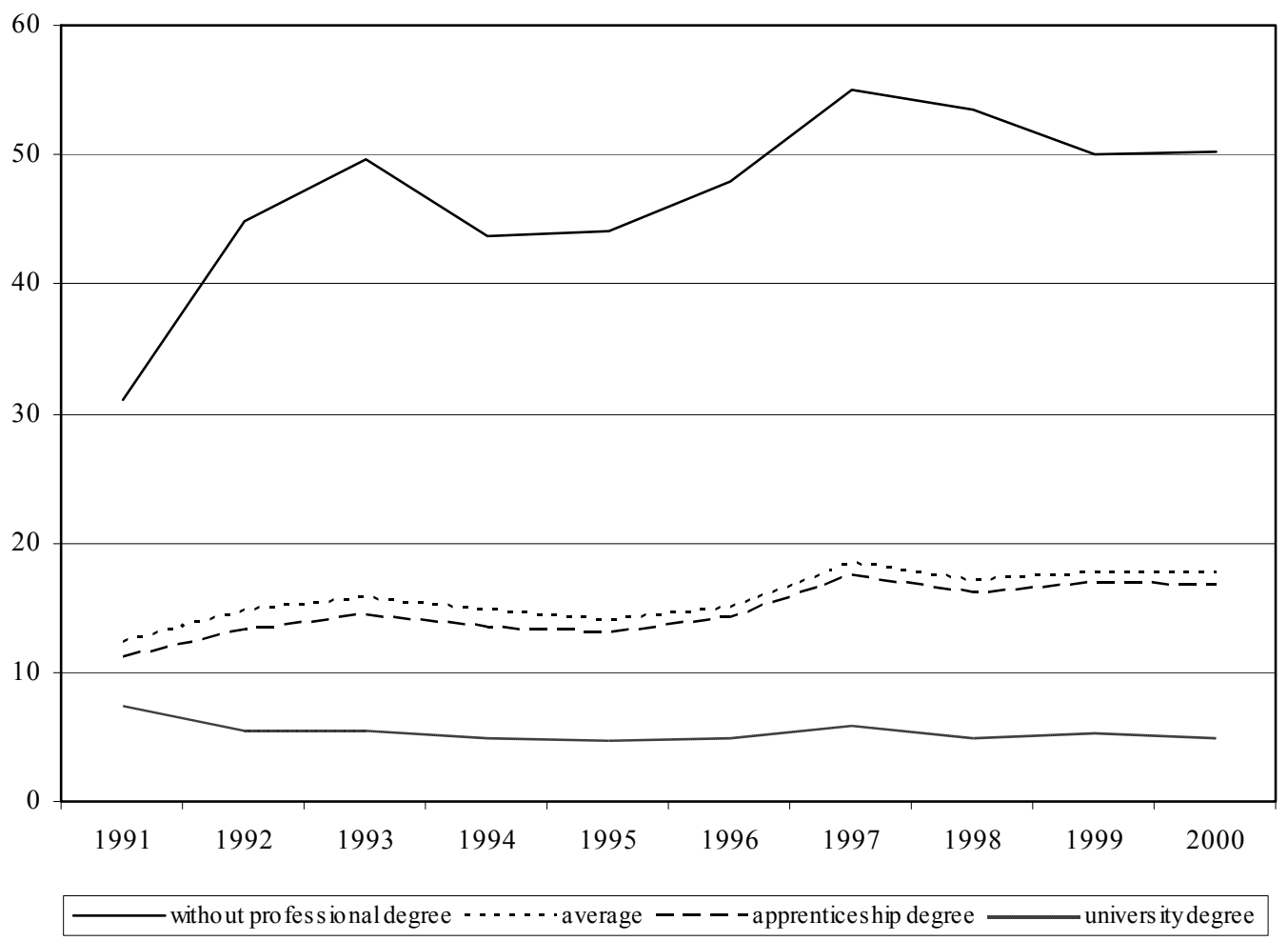

Source: IAB-Kurzbericht Nr. 9/2003

The empirical evidence on the impact of unemployment on the returns to education is incomplete and contradictory so far. In the wage curve literature, the impact of regional unemployment on wages is calculated for different qualification groups for example by Blanchflower and Oswald (1994) and Baltagi and Blien (1998). The latter find a stronger negative elasticity of lower educated on employment changes for Germany for 1981-1990. Blanchflower and Oswald (1994) also find this correlation for the US and Canada; for Australia and the UK they find a stronger negative wage elasticity for higher educated employees. In our approach we not only compare the wage elasticities of two or more distinct qualification groups with respect to regional unemployment, but also calculate the impact of unemployment on the returns to education for all employees.

Our model assumes for simplicity that employees only differ with respect to education. In reality, female labour participation usually reacts stronger during the business cycle than male labour participation (Killingsworth, 1983). In 
addition, females frequently follow males in their regional choices of jobs (Faggio and Nickell, 2005). Both effects might lead to a smaller impact of unemployment on female returns to education than on male returns.

Card (1995) argues that the wages of more senior workers are better isolated against changes in the labour market. Therefore, we hypothesize that also the returns to education change less for higher tenured employees during the business cycle.

Finally, we distinguish between different wage quantiles. We argue that employees at the lower end of the wage distribution rather leave the labour market if the unemployment increases than accept lower wages. This phenomen is especially virulent in Germany because the replacement ratio of unemployment or social benefits is rather high for lower wage groups.

We do not use long time-series or international comparisons in order to prove our hypotheses but rely on the persistent and large regional labour market variation in Germany (OECD, 2000). The unemployment rate is significantly higher in Eastern than in Western Germany for the considered period of time (1996-2003). In the late nineties, unemployment increased drastically in the eastern states (from 14 to 18 percentage points), but only moderately in the western states (from 8 to 9 percentage points). The unemployment rate recently stabilized at around 7 percentage points in Western and at around 17 percentage points in Eastern Germany (also compare Figures 2a and 2b). Disparities in economic indicators are not only found for Eastern and Western Germany but there is also variation across the German Länder within the two parts of the country (compare Figure 4 below for the variation in the unemployment ratio across the German Länder).

Using the regional variation of the German labour market in order to examine the relationship between unemployment and returns to education has several advantages. First, by measuring changes in a short period of time, we can exclude that long-term external skill demand changes with skill biased 
technological change. In addition, we can exclude that skill supply changes with changes in school quality or that changes in the skill composition of job seekers would confound the measured impact of changes in labour market conditions. Second, other studies face long time lags if they try to measure, for example, the effect of changes in school quality, skill demand changes induced by technological developments, migration or unemployment. These delayed effects do not play a role in our investigation. Third, by using regions within one country, we avoid measurement errors and data breaks that result from comparing different school systems, changes in classification criteria, different labour market institutions or unobservable country factors in international comparisons (de la Fuente and Doménech, 2006).

\subsection{Data}

Our main data source is the German Microcensus (MC) for 1996-2003. The microcensus is the official representative statistic of the population and the labour market, involving $1 \%$ of all households in Germany every year. The total number of households participating in the microcensus is about 370,000 (encompassing 820,000 persons), including about 70,000 households (about 160,000 persons) in the new Länder and the eastern part of Berlin.

All households have the same probability of selection for the microcensus. Within the territory of the Federal Republic of Germany, sampling districts are selected in which all households and persons are interviewed. Every year, a quarter of all households included in the sample are replaced. This means that every household stays in the sample for four years. Household numbers are not included in the Scientific Use File. Hence, the microcensus cannot be used as a panel.

The purpose of the microcensus is to provide statistical information on the economic and social situation of the population as well as on employment, on the labour market, and on education. The annual standard programme of the microcensus includes personal characteristics (age, sex, citizenship, etc.), 
family and household context. In addition, we know the main and the secondary place of residence, whether the individual is employed, on job search, unemployed or out of the labour force. There is information on the number of children at pre-primary age, pupils, students in the household and information on individual general and vocational level of qualification and on the level of the individual and household net incomes. The microcensus is the data set which is most adequate for our research purpose because it combines two advantages: a huge sample size and a large number of covariates on the individual level. The following variables are used in our estimations: net income $^{3}$, working time, qualification, job tenure, federal state (Land) the individual lives in, and personal characteristics (age and gender).

By dividing net income by working time, we derive hourly income. ${ }^{4}$ This is important because annual working hours are highly correlated with contemporaneous unemployment rates and therefore lower wages due to reduced working hours might bias our results (Card, 1995). We construct the variable "years of education" by using the information on the highest degree of schooling and professional education. We take the standard lengths of all primary, secondary, and tertiary school qualifications (e.g. 5 years for attending university) and add them up accordingly for each person. The variable "labour market experience" is constructed by substracting the years of education plus 6 from age. Hence, we use a proxy for potential labour market experience because we do not have direct information on labour market experience. In addition, we have information on tenure at the current job.

Besides the microcensus, we use the INKAR (an acronym for indicators and

\footnotetext{
${ }^{3}$ Net income is given in intervals. We take midpoints of the categories. The problem of earnings information given in categories is less severe than it first seems. First, categories are quite small (e.g. 24 income categories in 2000). Second, individuals usually don't know exactly the monthly income and therefore, measurement error should not be much higher than in other data sets.

${ }^{4}$ We restrict hourly earnings to a maximum of $154 €$ and a minimum of $1.02 €$. The upper limit affects only very few observations due to the categorical income variable and the lower limit affects less than 0.5 percent of the sample.
} 
maps of regional development) database and data provided by the German Federal Statistical Office. The INKAR database is published yearly by the Federal Office for Building and Regional Planning in co-operation with the Federal Statistical Office and the Statistical Offices of the German states (Länder). It regularly and topically describes the situation of the regional development in Germany and Europe. It includes about 20 indicators on topics such as age and population structure, employment or unemployment. From the INKAR database, the variable "average yearly unemployment rate on statelevel" is used.

\section{Empirical Evidence}

\subsection{Estimation Strategy}

Figure 3 provides first empirical evidence on the impact of regional unemployment on the returns to education. It shows a simple descriptive correlation between the wages of employees with a low and a high qualification level with the regional unemployment in the period 1996-2003. The wages of higher qualified employees are on average more sensitive to the regional unemployment rate. This implies a decrease in the returns to education when unemployment increases. The increasing sensitivity of wages with skills to the regional unemployment rate is also corroborated in Figure 4. We present here descriptive evidence that regional unemployment has a negative effect on regional returns to education. We use cross section evidence on the correlation between the regional unemployment rate in the 16 German Länder and the individual rates of financial returns to education. ${ }^{5}$ This figure also highlights the large gap in the labour market conditions between German regions.

\footnotetext{
${ }^{5}$ The financial rates of returns to education have been calculated according to the standard Mincer equation (4) shown below, also compare Table A6 in the appendix.
} 
Figure 3: Correlation between aggregate unemployment and qualification-specific hourly earnings

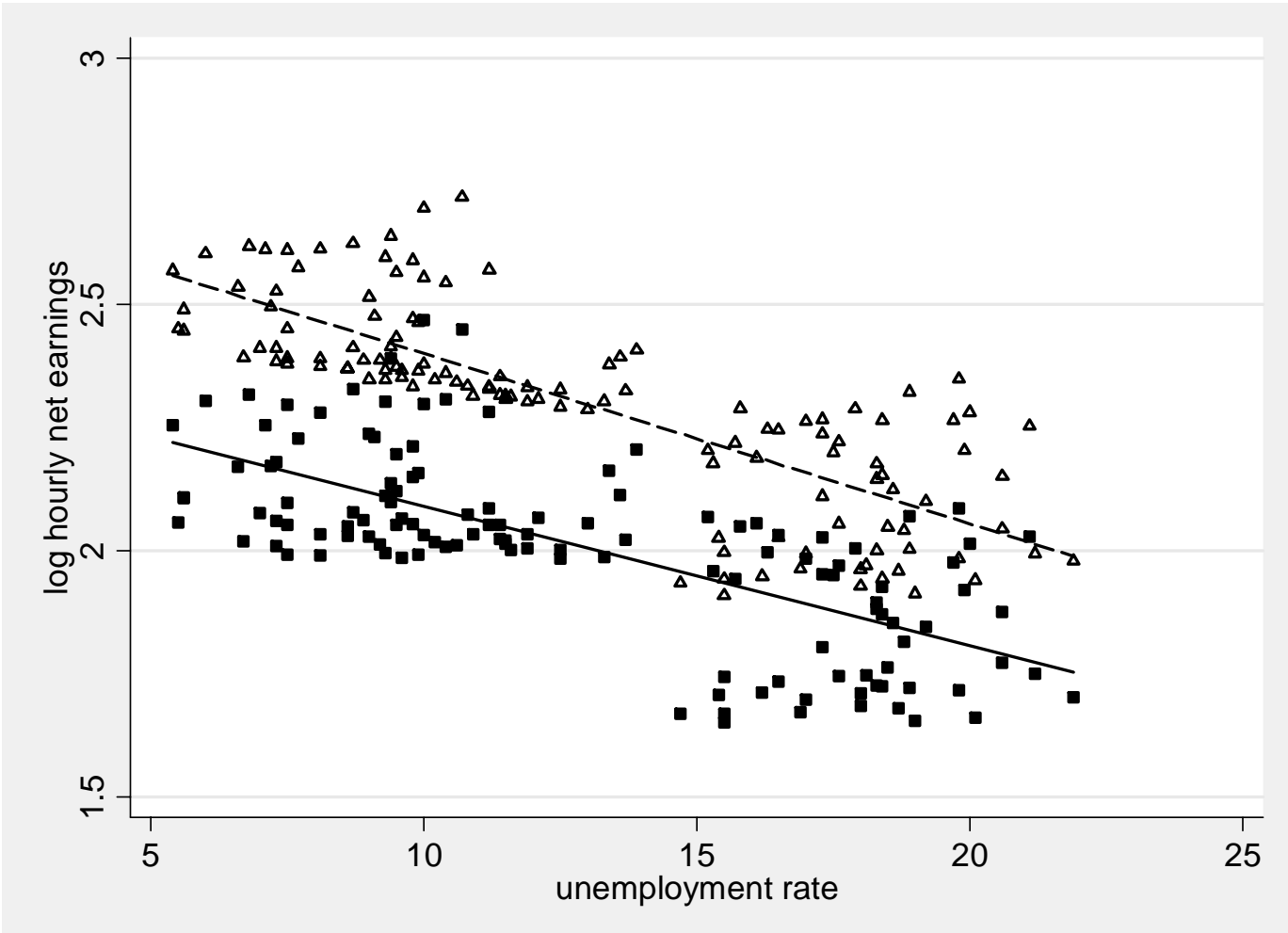

Source: Microcensus, waves 1996-2003.

Comments: The low educated include persons with no or lower vocational education (Lehre) while the high educated have tertiary or higher vocational education (Meister). The lines stem from linear regressions.

In order to explore multivariate explanations for returns to education, we first estimate standard Mincer equations, i.e. individual returns to education for employees in the private sector for the year 2003 using weighted least squares:

(4) $W_{i}=\beta_{0}+\beta_{1}$ educyears $s_{i}+\beta_{2}^{\prime} X_{i}+\varepsilon_{i}$,

where $W_{i}$ is the natural log of hourly earnings for individual $i$, educyears is the constructed number of education years, and $X$ is a vector of additional covariates including experience, experience squared, tenure, tenure squared and gender.

Then, analogously to the wage curve literature, we include the regional unemployment rate in the cross-section analysis in equation (4) in order to 
show that the regional unemployment rate has a negative impact on wages (compare Blanchflower and Oswald, 1990). In the theoretical considerations above we argued that also an interaction term between years of education and the regional unemployment rate should be included here because different regional unemployment rates affect higher education groups in another way than lower education groups.

If we include regional unemployment and the interaction term between unemployment and number of education years in the standard Mincer equation, our approach may suffer from so-called aggregation bias. Individuals in the same labour market may share some common component of variance that is not entirely attributable neither to their measured characteristics nor the regional unemployment rate (Moulton, 1990). This leads to a positive correlation of the error terms between members of the same regional labour market and an under-estimation of the standard-error of the covariates that are measured on the regional level. We allow for an interdependence of error terms at the state level and avoid a downward bias of the standard errors of aggregated variables (Moulton, 1986; 1990) by using cluster robust standard errors (White, 1980; Deaton, 1997) with Länder as clusters in estimating wage equations.

Moreover, in order to check the robustness of our results, a possible aggregation bias and endogeneity of unemployment in the wage regression, we propose an innovative two-step model that allows us to identify time lags and to use fixed effects and instrumental variables. This allows lags in the effect of unemployment on the returns to education and controls unobserved heterogeneity between regions (such as investments in schooling, efficiency of schooling, other differences in the schooling system or in industrial policy). In the first step, individual returns to education for each state and year are estimated analogously to equation (4) in a pooled model for 1996-2003 including regional and year dummies (but excluding the regional unemployment rate and the interaction between the unemployment rate and 
years of education). In the second estimation step the regional unemployment and the interaction term explain the average regional returns from education that have been calculated from the individual returns (Lucifora and Origo, 1999). Notice that in our two-step approach, the data have the same aggregation level in both steps and therefore aggregation bias is not an issue.

We apply several robustness checks that are not possible in the one step specification. In the first specification of the two-step estimation, the regional unemployment rate explains contemporary average returns to education in the regions. The first version of the second step of the estimation can therefore be written as:

(5) $R_{j t}=\tau_{t}+D_{j}+\gamma_{1}\left(U_{j t}\right)+u_{j t}$,

where $R_{j t}$ stands for the average returns to education on the state level from the first step regression according to equation (4). We have $j=16$ state dummies $D$ and $\tau=8$ time periods while $U_{j t}$ represents the state unemployment rate at time $t$. In the following three estimations, we explain the yearly change in returns to education in order to eliminate time-invariant unobserved heterogeneity between Länder. We also include lagged returns to education in these estimations because there might be time lags between regional unemployment and financial returns to education. In the fourth estimation model, we control in addition for a possible simultaneity bias caused by the endogeneity of regional unemployment by using lagged variables as instruments (Baltagi and Blien, 1998). 
Figure 4: Returns to education and unemployment rates, 2003

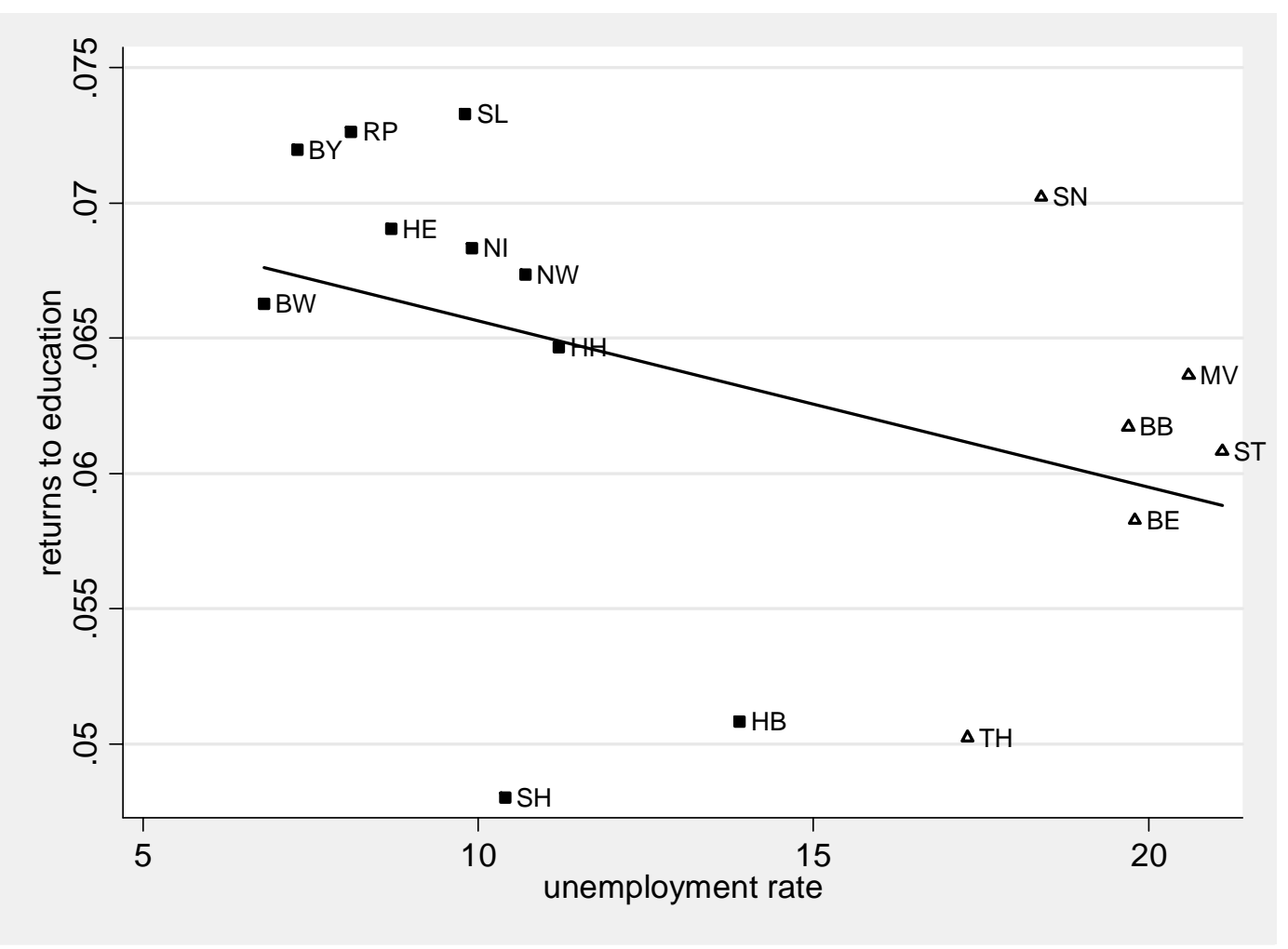

Key: Eastern states are represented by triangles, Western states by squares. The full names of the states can be found in Table A5. The results for the returns to education per state can be found in Table A6. The figure looks similar for any other year.

Source: Microcensus, INKAR.

One ongoing discussion surrounding the estimation of individual returns to education is the correction of estimates from the Mincer equation for measurement error in the education variable and a possible endogeneity bias of education (Card, 1995, 1999). Several authors propose the use of suitable instruments in order to reduce the measurement error and to correct for endogeneity. Our data set, the microcensus, does not offer promising variables which could be used as instruments in the individual wage equations. Moreover, our main interest lies in measuring the effect of local labour market conditions on the returns to education and not in calculating the precise value of the returns to education. When we assume that both - the measurement error in the education variable and a possible endogeneity bias - are not correlated with the local labour market conditions, the estimates of the interaction terms should be unbiased. Therefore, we refrain in this analysis from any attempt to correct the estimated effects of education for these well-studied biases - and 
their fiercly debated correction strategies - and focus on regional unemployment as a determinant of the returns to education.

\subsection{Empirical Results}

Our Mincer-type regressions estimated according to equation (4) with crosssection data of 2000 are presented in Table 1.

Table 1: Mincer equations for the cross-section of 2003

\begin{tabular}{lcc}
\hline \hline & $(1)$ & $(2)$ \\
\hline Years of education & $0.0641 * * *$ & $0.0666 * * *$ \\
Interaction U education & $(0.0029)$ & $(0.0020)$ \\
& - & $-0.0195 * * *$ \\
Experience & $0.0143 * * *$ & $(0.0044)$ \\
& $(0.0031)$ & $0.0177 * * *$ \\
Experience ${ }^{2}$ & $-0.0003 * * *$ & $(0.0017)$ \\
Tenure & $(0.00004)$ & $-0.0003 * * *$ \\
& $0.0164 * * *$ & $(0.00003)$ \\
Tenure ${ }^{2}$ & $(0.0023)$ & $0.0144 * * *$ \\
$\mathrm{R}^{2}$ & $-0.0002 * * *$ & $(0.0016)$ \\
Observations & $(0.00004)$ & $-0.0002 * * *$ \\
\hline \hline
\end{tabular}

Comments: Mincer equation for the cross section of 2003. Dependent variable is hourly net earnings. Specification (2) includes interaction term between regional unemployment, measured as percentage deviation from the mean, and years of education. Standard errors are clustered at the state level and reported in parentheses. Estimations are weighted by sampling probabilities. Significance levels: * ten percent, $* *$ five percent, ${ }^{* *}$ one percent. 
The estimates indicate that an additional year of education increases labour income by more than six percent. This is an estimate well-known from the empirical literature in Germany (Ammermueller and Weber, 2005; Steiner and Lauer, 2000) and other countries (Card, 1999; Harmon et al., 2001). If we include the interaction term between regional unemployment and years of education in this equation, we obtain significant negative effects of regional unemployment on the returns to education. This corresponds to our descriptive evidence and the theoretical argument that the wage bargaining power of skilled employees fluctuates stronger during the business cycle than the bargaining power of lower skilled employees. Keep in mind that we estimate all equations using the cluster command for regions in order to avoid aggregation bias.

In order to have better information (more individuals in the sample) and to use additional variation in the time series dimension, we use the information of the years 1996-2003 from the microcensus. When all years of the microcensus are pooled, 792,889 observations are available. The estimation of the financial returns to education hardly changes when including all eight years. The time dummies indicate that average wages increased every year during our observation period. In column (1) of Table 2 we present a German wage curve on the basis of our data using the regional unemployment rate and excluding the interaction term between education level and aggregate unemployment. We obtain a negative, albeit insignificant, impact of the regional unemployment level on individual wages. The size of the coefficient is comparable to that found in the literature for Germany (Baltagi and Blien, 1998; Nijkamp and Poot, 2005). The interaction term is added in column (2) and is significantly negative. If we also include yearly state dummies in the Mincer regression in order to control for differences between the wage developments in the Länder in column (3), both size and significance level of the interaction term hardly change. Adding state-specific covariates to the equation, i.e. state-specific returns to education as well as returns to experience and tenure, leads to a decrease of the coefficient of the interaction 
term, which is now just below the $10 \%$ significance level. The results indicate that an increase in the unemployment rate of one percent leads to a change of 0.008 to -0.004 percentage points in the returns to education. This is comparable to the effect of an increase of one percentage point in the regional unemployment rate from 10 to 11 percent on the returns to education of -0.08 to -0.04 , i.e. from 7.00 percent to 6.92 or 6.96 percent, for example.

Table 2: Mincer regressions for pooled data

\begin{tabular}{|c|c|c|c|c|}
\hline & ( 1 ) & ( 2 ) & (3) & (4) \\
\hline Years of & $0.0693 * * *$ & $0.0881 * * *$ & $0.0882 * * *$ & \\
\hline education & $(0.0016)$ & $(0.0075)$ & $(0.0077)$ & \\
\hline \multirow{2}{*}{ Regional U rate } & -0.0609 & 0.0431 & & \\
\hline & $(0.0656)$ & $(0.0603)$ & & \\
\hline Interaction U & & $-0.0083 * *$ & $-0.0083 * *$ & -0.0043 \\
\hline education & & $(0.0030)$ & $(0.0031)$ & $(0.0025)$ \\
\hline \multicolumn{5}{|l|}{ Controls: } \\
\hline Individual & $\checkmark$ & $\checkmark$ & $\checkmark$ & $\checkmark$ \\
\hline Year and state & $\checkmark$ & $\checkmark$ & & \\
\hline State $*$ year & & & $\checkmark$ & $\checkmark$ \\
\hline $\begin{array}{l}\text { State-specific } \\
\text { covariates }\end{array}$ & & & & $\checkmark$ \\
\hline $\mathrm{R}^{2}$ & 0.2256 & 0.2258 & 0.2305 & 0.2352 \\
\hline Observations & 792889 & 792889 & 792889 & 792889 \\
\hline
\end{tabular}

Comments: Mincer equations for the pooled data 1996-2003. Dependent variable is hourly net earnings. All specifications include an interaction term between regional unemployment, measured as percentage deviation from the mean, and years of education. Individual controls as in Table 1. Standard errors are clustered at the state level and reported in parentheses. Estimations are weighted by sampling probabilities. Significance levels: * ten percent, ** five percent, $* * *$ one percent.

Please note that we use state*year dummies as controls for the regional labour market situation in specifications (3) and (4) instead of the regional unemployment rate as proposed by several commentators in the wage curve literature. The state*year specific intercepts provide a better control for 
differences across regional labour markets and over time and impose thus fewer restrictions on the estimated model.

Further regression estimates are reported in the appendix. Table A2 presents the results for estimations by gender and region. For men, the interaction term is highly significant and slightly larger than in Table 2. No significant relationship between regional unemployment and returns to education is reported for women. This supports our hypothesis that females react stronger to changes in unemployment by leaving the labour market instead of accepting wage cuts, while males see their wages fluctuate stronger during the business cycle. If we separate our regressions between East and West Germany, a slightly significant influence of the regional unemployment rate on the returns to education can only be detected for West but not for East Germany.

In Table A3, further interactions between the "years of education*regional unemployment" interaction term and tenure have been added to the wage equation. We expect a positive sign for the tenure interaction term because wages in internal labour markets should be less sensitive to cyclical shocks. The results are not clear-cut. When we include a linear interaction term, the coefficient is positive but not significant. It turns significant, however, once we add a squared interaction term. Using an interaction term between a dummy for having ten or more years of tenure and the interaction term between years of education and regional unemployment yields insignificant results.

Further estimations to test the sensitivity of the results are presented in Table A4. The regressions according to specification (3) in Table 2 have been performed for commuters and non-commuters, i.e. people living and working in the same state. This is important because individual wages of the employees are connected with the unemployment rate of their place of residence. If they commute, their income is affected by a different labour market, however. The interaction effects are again negative and significant and slightly higher for commuters. 
Finally, we include also unemployed persons in the regressions and use monthly income as the dependent variable (column 3). Thereby, we can test whether the composition of our sample biases the results. Our regular sample includes only employed persons and its composition is affected by the unemployment rate each year. By including both employed and unemployed persons, we avoid a possible sample selection bias. The drawback is that we can only use net monthly income as our dependent variable instead of the more precise hourly wages. The results in column (3) of Table A4 show that the interaction effect is highly significant again and even slightly stronger in absolute terms compared to the pooled regression results in Table 2 .

Finally we present the results of our two-step estimation procedure. In the second estimation step shown in Table 3, we first explain average regional returns to education by the regional unemployment rate. The contemporary regional unemployment rate is negatively related to returns to education on the regional level but does not have a significant impact. If we take unobserved heterogeneity of regions into account by using yearly changes in returns to education as the dependent variable in columns (2) to (4), regional unemployment has the significant negative influence we also derived in the one step models. The negative effect or regional unemployment on returns to education is persistent, compare column (3) - also lagged regional unemployment has a comparable impact on the returns to education (this is also found by Vilhubert, 1999 for Germany and Lucifora and Origo, 1999 for Italy). If we use the lagged unemployment rate as an instrument for contemporary unemployment in column (4), the regional unemployment coefficient is almost unchanged, while it turns insignificant. ${ }^{6}$

\footnotetext{
${ }^{6}$ Using the lagged unemployment rate by one and two years is a strong instrument - the impact on contemporary unemployment is jointly significant at the one percent level, compare Staiger and Stock (1997).
} 
Table 3: Results from two-step estimations

\begin{tabular}{|c|c|c|c|c|}
\hline \multirow[t]{2}{*}{ Dependent variable } & \multirow{2}{*}{$\begin{array}{l}\text { Returns to } \\
\text { education } \\
(1)\end{array}$} & \multicolumn{3}{|c|}{ Yearly changes in returns to education } \\
\hline & & (2) & (3) & (4) \\
\hline \multirow{2}{*}{ Regional U rate } & -0.0035 & $-0.0046^{*}$ & & -0.0047 \\
\hline & $(0.0029)$ & $(0.0025)$ & & $(0.0032)$ \\
\hline \multirow{2}{*}{ Lagged regional $\mathrm{U}$} & & \multirow{2}{*}{\multicolumn{3}{|c|}{$\begin{array}{l}-0.0046^{*} \\
(0.0026)\end{array}$}} \\
\hline & & & & \\
\hline \multicolumn{5}{|l|}{ Controls: } \\
\hline Year and state & $\checkmark$ & $\checkmark$ & $\checkmark$ & $\checkmark$ \\
\hline $\begin{array}{l}\text { Lagged returns to } \\
\text { education }\end{array}$ & & $\checkmark$ & $\checkmark$ & $\checkmark$ \\
\hline $\begin{array}{l}\text { Yearly change in } \\
\text { unemployment rate }\end{array}$ & & & $\checkmark$ & \\
\hline IV lagged regional $\mathrm{U}$ & & & & $\checkmark$ \\
\hline $\mathrm{R}^{2}$ & 0.8574 & 0.8131 & 0.8131 & 0.8131 \\
\hline Observations & 128 & 112 & 112 & 112 \\
\hline
\end{tabular}

Comments: Estimates of log regional unemployment rates in columns (1), (2) and (4) and lagged log unemployment rate in column (4) from second step regression. Returns to education are taken from first stage regression of log hourly earnings on state*year specific years of schooling variables, experience, experience squared, tenure, tenure squared and gender, year and state dummies. Dependent variable: returns to education in column (1), yearly change in returns to education in columns (2), (3) and (4). Controls are year and state dummies in column (1), year and state dummies and lagged returns to education in column (2), year and state dummies, lagged returns to education and yearly change in unemployment rate in column (3), year and state dummies and lagged returns to education in column (4). Unemployment rate is instrumented by first and second lag of unemployment rate in column (4). Regressions are weighted by inverse of cluster robust standard errors of the returns to education in first stage. Significance levels: * ten percent, $* *$ five percent, $* * *$ one percent.

The two-step estimation results imply that a ten percent increase in the regional unemployment rate, e.g. from ten to eleven percent, leads to a decrease in the estimated returns to education by 0.05 , e.g. from 7.00 to 6.95 
percent. We prefer the lower estimate of the two step approach to the previous one step estimates from Table 2 because we can control better for heterogeneity across states now.

Table 4: Results from two-step estimation for quantile regressions

\begin{tabular}{lccccc}
\hline \hline & 1. Decile & 2. Decile & 3. Decile & 4. Decile & 5. Decile \\
\hline $\begin{array}{l}\text { Regional U } \\
\text { rate }\end{array}$ & 0.0006 & $-0.0022^{* *}$ & 0.0008 & $-0.0043^{* * *}$ & $-0.0031^{* * *}$ \\
$\begin{array}{l}\text { Lagged } \\
\text { regional U } \\
\text { rate }\end{array}$ & $-0.0027^{*}$ & -0.0017 & $-0.0019 *$ & $-0.0041^{* * *}$ & $-0.0025^{* *}$ \\
& $(0.0016)$ & $(0.0013)$ & $(0.0010)$ & $(0.0010)$ & $(0.0010)$ \\
\hline $\begin{array}{l}\text { Regional U } \\
\text { rate }\end{array}$ & $-0.0021^{*}$ & $-0.0026^{*}$ & -0.0028 & $-0.0118^{* *}$ & - \\
$\begin{array}{l}\text { Lagged } \\
\text { regional U } \\
\text { rate }\end{array}$ & $(0.0011)$ & $(0.0013)$ & $(0.0018)$ & $(0.0057)$ & - \\
\hline \hline
\end{tabular}

Comments: Estimates of log regional unemployment rates in first row and lagged log unemployment rate in second row from second step regression. Dependent variable: Returns to education taken from first stage quantile regression of log hourly earnings on state*year specific years of schooling variables, experience, experience squared, tenure, tenure squared and gender, year and state dummies. Dependent variable: returns to education in first row and yearly change in returns to education in second row. Controls are year and state dummies in first row and year and state dummies, lagged returns to education and yearly change in unemployment rate in second row. Regressions are weighted by inverse of standard errors of the returns to education in first stage. Number of observations is 128 for first row and 112 for second row. Significance levels: $*$ ten percent, $* *$ five percent, $* * *$ one percent.

We also estimate the impact of the regional unemployment rate and the lagged regional unemployment rate on the returns to education for the income deciles based on the individual first-step quantile regressions. We find that indeed the impact of the business cycle on the returns to education is somewhat lower for the first deciles than for the other deciles. This (weakly) supports our hypothesis that low wage earners in Germany rather leave the labour market in depressions than accept reduced wages. 


\section{Conclusions}

This paper demonstrates that the regional unemployment rate has a negative impact on the returns to education. Therefore, time-series analyses or international or regional comparisons of the financial effects of education should include the aggregate unemployment rate in order to avoid biased results.

The significant impact of regional unemployment on individual returns shows that the wage situation of skilled employees is stronger affected by changes in the regional labour market than wages of unskilled employees. This is the consequence of a more sensitive wage bargaining position of the higher skilled during the business cycle. This is an important result because so far mainly the isolation of higher skilled employees from labour market swings with respect to their employment situation instead of their wages has been highlighted in the literature. We also show that returns to education for males are stronger affected from aggregate unemployment than those for females. The evidence on employees with different tenure is mixed. Lower wage quantiles are less affected - we interpret this as an indicator for a stronger inclination of low wage employees to leave the labour market instead of accepting lower wages in Germany.

On average we find that an increase in the regional unemployment rate by one percentage point can explain a decrease in the financial returns of an additional year of education by around 0.005 percentage points. This is a nonnegligible impact in economic terms. If we compare the state with the highest unemployment rate, Saxony-Anhalt, to Bavaria, the state with the lowest unemployment rate during our observation period, regional labour market conditions can explain a difference in returns to education of 0.91 percentage points. In other words, if an employee moves from Saxony-Anhalt to Bavaria, he or she will, on average, encounter an increase in financial returns to an additional year of schooling of 14 percent. The observed difference in the returns to education between the two states is on average 0.89 percentage 
points. Therefore, the estimated impact of the regional unemployment rate can almost perfectly explain the observed differences in the rates of return.

We use regional information and official data that are representative for Germany in the period 1996-2003. We are striving to avoid measurement error by using hourly wages instead of monthly or yearly wages that are affected by changing working time during the business cycle. In addition, we find that our results are unchanged if including only employees who do not commute to another region or if including also the unemployed in our sample. We also take into account possible lagged effects of changes in regional unemployment on changes of the financial returns from one additional year of education. In addition, we use fixed-effects estimations to get rid of unobserved timeinvariant heterogeneity between regions. Finally, we instrument the impact of unemployment on returns to education using the lagged values as instruments in order to avoid endogeneity. These specifications qualitatively produce the same results although the two-step estimates are smaller in absolute size than the estimates from the pooled model. 


\section{Literature}

Acemoglu, D. (1998): Why Do New Technologies Complement Skills? Directed Technical Change and Wage Inequality, Quarterly Journal of Economics 113, 1055-1089.

Acemoglu, D. (1999): Changes in Unemployment and Wage Inequality: An Alternative Theory and Some Evidence, American Economic Review $89,1259-1278$.

Ammermueller, A. and A.M. Weber (2005): Educational attainment and returns to education in Germany: An analysis by subject of degree, gender and region, ZEW Discussion Paper No. 05-17, Mannheim.

Baltagi, B., U. Blien (1998): The German wage curve - evidence from the IAB employment sample, Economics Letters, 61, 135-142.

Barro, R., J. Lee (1996): International measures of schooling years and schooling quality, American Economic Review Papers and Proceedings 86(2), 218-23.

Berman, E., J. Bound, Z. Griliches (1994): Changes in the demand for skilled labor within U.S. Manufacturing: Evidence from the annual survey of manufacturers, Quarterly Journal of Economics, 109, 367-397.

Blanchflower, D., A. Oswald (1990): The Wage Curve, Scandinavian Journal of Economics, 92 (2), 215-235.

Blanchflower, D., A. Oswald (1994): The Wage Curve, Cambridge (Mass.): MIT Press.

Büttner, T., B. Fitzenberger (1998): Central Wage Bargaining and Local Wage Flexibility: Evidence from the Entire Wage Destribution, ZEW Discussion Paper No. 98-39, Mannheim

Campbell, D. (2001): Rates of return to schooling and the quality of education in England and Wales, mimeo, University of Kent at Canterbury, Canterbury.

Card, D. (1995): The Wage Curve: A Review, Journal of Economic Literature, 33 (2), 758-799.

Card, D. (1999): The causal effect of education on earnings, in: Ashenfelter, O., D. Card (eds.): Handbook of Labour Economics, Vol. 3A, Chapter 30, Elsevier: Amsterdam, 1801-1863

Card, D., A. Krueger (1992): Does school quality matter? Returns to education and the characteristics of public schools in the United States, Journal of Political Economy, 100 (1), 1-40.

Deaton, A. (1997): The analysis of household surveys, John Hopkins University Press, Baltimore and London.

Devereux, P. (2005): Effects of Industry Growth and Decline on Gender and Education Wage Gaps in the 1980s, Industrial and Labor Relations Review, 58 (4), 552-570.

Faggio, G., S. Nickell (2005): The responsiveness of wages to labour market conditions in the UK, Labour Economics, 12 (5), 685-696. 
Fuente, A. de la, A. Ciccone (2002): Human Capital in an Global and Knowledge-Based Economy, final report for European Commission, Directorate General for Employment and Social Affairs, Brussels.

Fuente, A. de la, R. Doménech (2006): Human Capital in Growth Regressions: How Much Difference Does Data Quality Make?, Journal of the European Economic Association, 4(1), 1-36.

Fitzenberger, B. (1999): Wages and employment across skill groups: An analysis for West Germany, ZEW Economic Studies 6, Physica: Heidelberg.

Hamermesh, D. (1993): Labor demand, Princeton University Press: Princeton NJ.

Harmon, C., I. Walker, N. Westergaard-Nielsen (2001): Education and earnings in Europe. A cross-country analysis of the returns to education, Edward Elgar: Cheltenham.

Hawley, J. (2004): Changing returns to education in times of prosperity and crisis, Thailand 1985-1998, Economics of Education Review, 23, 273286.

Jacobebbinghaus, P., T. Zwick (2002): New technologies and the demand for medium qualified labour in Germany, Schmollers Jahrbuch, 122 (2), 179-206.

Katz, L., K. Murphy (1992): Changes in Relative Wages, 1963-1987: Supply and Demand Factors, Quarterly Journal of Economics, 107 (1), 35-78.

Killingsworth, M. (1983): Labor Supply, Cambridge University Press, New York.

Krugman, P. (1994): Past and Prospective Causes of High Unemployment, Economic Review of the Federal Reserve Bank of Kansas City, 23-43.

Kuckulenz, A., T. Zwick (2003): The Impact of Training on Earnings Differences Between Participant Groups and Training Forms, ZEW Discussion Paper No. 03-57, Mannheim.

Lauer, C. (2003): Education and unemployment: A French-German comparison, ZEW Discussion Paper No. 03-34, Mannheim.

Lucifora, C., F. Origo (1999): Alla ricerca della flessibilità: un'analisi della curva dei salari in Italia, Rivista Italiana degli Economisti, 3, 1-29.

Machin, S., J. van Reenen (1998): Technology and changes in skill structure: Evidence from seven OECD countries, Quarterly Journal of Economics, 113 (4), 1215-1244.

Mincer, J. (1974): Schooling, experience and earnings, Columbia University Press: New York.

Mincer, J. (1991): Education and unemployment, NBER Working Paper 3838, Cambridge, MA.

Moulton, B. (1986): Random group effects and the precision of regression estimates, Journal of Econometrics 32(3), 385-397.

Moulton, B. (1990): An illustration of a pitfal in estimating the effects of aggregate variables on micro units, Review of Economics and Statistics, 32, pp. 334-338. 
Nickell, S., S. Wadhwani (1990): Insider forces and wage determination, Economic Journal, 100, pp. 496-509.

Nijkamp, P., J. Poot (2005): The Last Word in the Wage Curve? Journal of Economic Surveys, 19 (3), 421-450.

OECD (2000): Employment Outlook, chapter 2, pp. 31-78, Organisation for Economic Co-operation and Development Employment, Paris.

Oi, W. (1962): Labor as a Quasi-fixed Factor, Journal of Political Economy, $70(2), 538-555$.

Ours, van, J., G. Ridder (1995): Job matching and job competiton: Are lower educated workers at the back of job queues?, European Economic Review, 39, 1717-1731.

Pannenberg, M., J. Schwarze (1998): Labor Market Slack and the Wage Curve, Economics Letters, 58, 351-354.

Reinberg, A., M. Hummel (2002): Qualifikation bestimmt Position auf dem Arbeitsmarkt, IAB Kurzbericht 15/2002, Nuremberg.

Steiner, V., C. Lauer (2000): Private Erträge von Bildungsinvestitionen in Deutschland, Beihefte der Konjunkturpolitik, Applied Economics Quarterly 51, 71-101.

Vilhubert, L. (1999): Wage Flexibility and Contract Structure in Germany, mimeo, Université de Montréal.

White, H. (1980): A heteroskedasticity-consistent covariance matrix estimator and direct test for heteroskedasticity, Econometrica 48(4), 817-828.

Wilke, R. (2004): New estimates of the duration and risk of unemployment in West-Germany, ZEW Discussion Paper 04-26, Mannheim.

Wood, S. (1995): How trade hurt unskilled workers, Journal of Economic Perspectives, 9(3), 57-80. 


\section{Appendix}

Table A1: Descriptive statistics

\begin{tabular}{lcccccccc}
\hline \hline & 1996 & 1997 & 1998 & 1999 & 2000 & 2001 & 2002 & 2003 \\
\hline \hline Ln hourly & 2.03 & 2.04 & 2.06 & 2.08 & 2.11 & 2.26 & 2.31 & 2.32 \\
income & $(0.50)$ & $(0.49)$ & $(0.49)$ & $(0.50)$ & $(0.51)$ & $(0.75)$ & $(0.75)$ & $(0.74)$ \\
Years of & 12.29 & 12.37 & 12.43 & 12.38 & 12.41 & 12.46 & 12.53 & 12.62 \\
education & $(2.34)$ & $(2.33)$ & $(2.37)$ & $(2.38)$ & $(2.38)$ & $(2.40)$ & $(2.48)$ & $(2.56)$ \\
& 22.04 & 22.00 & 22.01 & 22.13 & 22.16 & 22.34 & 22.49 & 22.58 \\
Experience & $(10.21)$ & $(10.13)$ & $(10.06)$ & $(9.91)$ & $(9.77)$ & $(9.73)$ & $(9.69)$ & $(9.68)$ \\
& 589.76 & 586.77 & 585.47 & 587.66 & 586.46 & 593.72 & 599.43 & 603.78 \\
Experience & $(483.9)$ & $(480.7)$ & $(477.8)$ & $(472.0)$ & $(465.2)$ & $(463.5)$ & $(460.3)$ & $(459.0)$ \\
& 10.56 & 10.62 & 10.60 & 10.44 & 10.31 & 10.34 & 10.50 & 10.74 \\
Tenure & $(9.69)$ & $(9.70)$ & $(9.70)$ & $(9.62)$ & $(9.61)$ & $(9.63)$ & $(9.65)$ & $(9.68)$ \\
& 205.57 & 206.96 & 206.37 & 201.56 & 198.72 & 180.12 & 165.30 & 153.55 \\
Tenure & $(323.2)$ & $(326.4)$ & $(326.9)$ & $(321.8)$ & $(320.1)$ & $(301.6)$ & $(287.1)$ & $(273.5)$ \\
& 0.63 & 0.63 & 0.63 & 0.62 & 0.62 & 0.62 & 0.61 & 0.61 \\
Male & $(0.48)$ & $(0.48)$ & $(0.48)$ & $(0.48)$ & $(0.48)$ & $(0.49)$ & $(0.49)$ & $(0.49)$ \\
& 10.95 & 12.15 & 11.10 & 10.85 & 9.61 & 9.59 & 10.15 & 10.85 \\
Regional U & $(2.94)$ & $(3.91)$ & $(3.56)$ & $(4.11)$ & $(4.32)$ & $(4.47)$ & $(4.33)$ & $(4.36)$ \\
Deviation of & 3.08 & 14.37 & 4.47 & 2.10 & -9.58 & -9.80 & -4.53 & 2.10 \\
regional U & $(27.65)$ & $(36.83)$ & $(33.52)$ & $(38.70)$ & $(40.64)$ & $(42.08)$ & $(40.77)$ & $(40.99)$ \\
\hline Observations & 101603 & 100245 & 99470 & 100329 & 99285 & 103702 & 101922 & 98568 \\
\hline \hline
\end{tabular}

Comment: Means are weighted by sampling probability, standard deviations in parentheses. 
Table A2: Estimations by region and gender

\begin{tabular}{lcccc}
\hline \hline & East & West & Men & Women \\
\hline \hline Years of & $0.0732 * *$ & $0.0910 * * *$ & $0.0934^{* * *}$ & $0.0627 * * *$ \\
education & $(0.0241)$ & $(0.0109)$ & $(0.0095)$ & $(0.0078)$ \\
Interaction U & -0.0042 & $-0.0091^{*}$ & $-0.0084 * *$ & -0.0024 \\
education & $(0.0080)$ & $(0.0046)$ & $(0.0038)$ & $(0.0032)$ \\
Controls: & & & & \\
Individual & $\checkmark$ & $\checkmark$ & $\checkmark$ & $\checkmark$ \\
State & $\checkmark$ & $\checkmark$ & $\checkmark$ & $\checkmark$ \\
Year & $\checkmark$ & $\checkmark$ & $\checkmark$ & $\checkmark$ \\
State $*$ year & $\checkmark$ & $\checkmark$ & $\checkmark$ & $\checkmark$ \\
\hline R & 0.1901 & 0.2033 & 0.2484 & 0.1185 \\
Observations & 161459 & 631430 & 489717 & 303172 \\
\hline \hline
\end{tabular}

Comments: Mincer equation for the pooled data 1996-2003. Dependent variable is hourly net earnings. All specifications include an interaction term between regional unemployment, measured as percentage deviation from the mean, and years of education. Individual controls as in Table 1. Standard errors are clustered at the state level and reported in parentheses. Estimations are weighted by sampling probabilities. Significance levels: * ten percent, ** five percent, $* * *$ one percent. 
Table A3: Estimations including interactions with tenure

\begin{tabular}{|c|c|c|c|}
\hline Tenure measure & Linear & Squared & Dummy \\
\hline Years of education & $\begin{array}{c}0.0869 * * * \\
(0.0072)\end{array}$ & $\begin{array}{c}0.0857 * * * \\
(0.0071)\end{array}$ & $\begin{array}{c}0.0879 * * * \\
(0.0076)\end{array}$ \\
\hline $\begin{array}{l}\text { Interaction U } \\
\text { education }\end{array}$ & $\begin{array}{l}-0.0085 * * \\
(0.0031)\end{array}$ & $\begin{array}{c}-0.0102 * * * \\
(0.0031)\end{array}$ & $\begin{array}{c}-0.0083 * * \\
(0.0030)\end{array}$ \\
\hline $\begin{array}{l}\text { Interaction U } \\
\text { education*tenure }\end{array}$ & $\begin{array}{c}0.00008 \\
(0.00006)\end{array}$ & $\begin{array}{c}0.00067 * * * \\
(0.00008)\end{array}$ & - \\
\hline $\begin{array}{l}\text { Interaction U } \\
\text { education*tenure }\end{array}$ & - & $\begin{array}{c}-0.000019^{* * *} \\
(0.0000023)\end{array}$ & - \\
\hline $\begin{array}{l}\text { Interaction } U \\
\text { education } \\
* \text { tenure }>=10\end{array}$ & - & - & $\begin{array}{l}-0.0003 \\
(0.0002)\end{array}$ \\
\hline \multicolumn{4}{|l|}{ Controls: } \\
\hline Individual & $\checkmark$ & $\checkmark$ & $\checkmark$ \\
\hline State & $\checkmark$ & $\checkmark$ & $\checkmark$ \\
\hline Year & $\checkmark$ & $\checkmark$ & $\checkmark$ \\
\hline State $*$ year & $\checkmark$ & $\checkmark$ & $\checkmark$ \\
\hline $\mathrm{R}^{2}$ & 0.2306 & 0.2311 & 0.2305 \\
\hline Observations & 792889 & 792889 & 792889 \\
\hline
\end{tabular}

Comments: Mincer equation for the pooled data 1996-2003. Dependent variable is hourly net earnings. All specifications include an interaction term between regional unemployment, measured as percentage deviation from the mean, and years of education. Further interaction terms are between tenure and regional unemployment. Individual controls as in Table 1. Standard errors are clustered at the state level and reported in parentheses. Estimations are weighted by sampling probabilities. Significance levels: * ten percent, ${ }^{* *}$ five percent, $* * *$ one percent. 
Table A4: Sensitivity estimations

\begin{tabular}{lccc}
\hline \hline & Non-commuters & Commuters & $\begin{array}{c}\text { Employees and } \\
\text { unemployed }\end{array}$ \\
\hline \hline $\begin{array}{l}\text { Years of } \\
\text { education }\end{array}$ & $0.0924 * * *$ & $0.1096^{* * *}$ & $0.1101^{* * *}$ \\
Interaction U & $(0.0073)$ & $(0.0067)$ & $(0.0089)$ \\
Controls: & $(0.0030)$ & $-0.0163 * * *$ & $-0.0109 * * *$ \\
Individual & $\checkmark$ & $(0.0025)$ & $(0.0035)$ \\
State & $\checkmark$ & & $\checkmark$ \\
Year & $\checkmark$ & $\checkmark$ & $\checkmark$ \\
State*year & $\checkmark$ & $\checkmark$ & $\checkmark$ \\
\hline $\mathrm{R}^{2}$ & 0.2552 & $\checkmark$ & $\checkmark$ \\
Observations & 402786 & 0.2606 & 0.3015 \\
\hline \hline
\end{tabular}

Comments: Mincer equation for the pooled data 1996-2003. Dependent variable is hourly net earnings. All specifications include an interaction term between regional unemployment, measured as percentage deviation from the mean, and years of education. Individual controls as in Table 1. For the estimation using monthly income as the dependent variable (column (3)), both employed and unemployed persons are included in the regressions. The invidual controls include experience, experience squared and sex. Standard errors are clustered at the state level and reported in parentheses. Estimations are weighted by sampling probabilities. Significance levels: $*$ ten percent, $* *$ five percent, $* * *$ one percent. 
Table A5: Names of the 16 German states and their abbreviations

\begin{tabular}{lc}
\hline \hline State Name & Abreviation \\
\hline Baden-Wuerttemberg & BW \\
Bavaria & BY \\
Berlin & BE \\
Brandenburg & BB \\
Bremen & $\mathrm{HB}$ \\
Hamburg & $\mathrm{HH}$ \\
Hesse & $\mathrm{HE}$ \\
Lower Saxony & $\mathrm{NI}$ \\
Mecklenburg-Western Pom. & $\mathrm{MV}$ \\
North Rhine-Westphalia & $\mathrm{NW}$ \\
Rhineland-Palatinate & $\mathrm{RP}$ \\
Saarland & $\mathrm{SL}$ \\
Saxony & $\mathrm{SN}$ \\
Saxony-Anhalt & $\mathrm{ST}$ \\
Schleswig-Holstein & $\mathrm{SH}$ \\
Thuringia & $\mathrm{TH}$ \\
\hline \hline
\end{tabular}


Table A6: Returns to education by state for 2003

\begin{tabular}{lc}
\hline \hline State & Returns to Education \\
\hline Baden-Wuerttemberg & .066 \\
Bavaria & .072 \\
Berlin & .058 \\
Brandenburg & .062 \\
Bremen & .051 \\
Hamburg & .065 \\
Hesse & .069 \\
Lower Saxony & .068 \\
Mecklenburg-Western Pom. & .064 \\
North Rhine-Westphalia & .067 \\
Rhineland-Palatinate & .073 \\
Saarland & .073 \\
Saxony & .070 \\
Saxony-Anhalt & .061 \\
Schleswig-Holstein & .048 \\
Thuringia & .050 \\
\hline \hline
\end{tabular}

State-specific returns to education, estimated in a regression of log hourly earnings on statespecific years of schooling variables, experience, experience squared, tenure, tenure squared, a gender dummy and state dummies in the cross-section of 2003. 